\title{
Short hairpin RNA directed against $\beta$-catenin inhibits prostate cancer growth and invasion in vitro
}

\author{
JIAHUI ZHAO $^{1}$, CHUNTING WU $^{2}$, YONG LUO ${ }^{1}$ and YONGGUANG JIANG ${ }^{1}$ \\ Departments of ${ }^{1}$ Urology and ${ }^{2}$ Respiratory and Critical Care Medicine, Beijing Anzhen Hospital, \\ Capital Medical University, Beijing 100029, P.R. China
}

Received October 22, 2015; Accepted October 25, 2016

DOI: $10.3892 / \mathrm{mmr} .2016 .6067$

\begin{abstract}
. $\beta$-catenin protein exhibits a dual function in epithelial cells, depending on its intracellular localization. At the plasma membrane, $\beta$-catenin is an important constituent of adherens junctions. However, when the $\mathrm{Wnt} / \beta$-catenin signaling pathway is activated, $\beta$-catenin translocates to the nucleus to promote specific gene expression. To investigate the functional activity and examine the role of the $\mathrm{Wnt} / \beta$-catenin signaling pathway in various human prostate cancer cells, indirect immunofluorescence was performed to detect the expression and distribution of $\beta$-catenin in the following prostate cancer cell lines: PC-3, LNCaP, C4-2, IA8-ARCaP and IF11-ARCaP. A marked difference was observed in the expression and distribution of $\beta$-catenin in different prostate cancer cell lines. $\beta$-catenin was observed in the nuclei of IA8-ARCaP and IF11-ARCaP cell lines, whereas it was present on the membrane of LNCaP and C4-2 cell lines. There was a low expression of $\beta$-catenin in the PC-3 cell line. Furthermore, short hairpin RNA (shRNA) targeting human $\beta$-catenin was constructed to investigate the effect of $\beta$-catenin shRNA on the proliferation and invasive potency of prostate cancer cells. The IA8/ $\beta$-catenin(-) cell line exhibited a reduced potency for invasion and proliferation compared with the IA8 and IA8-shControl groups. The present study demonstrated that suppressing activity of $\mathrm{Wnt} / \beta$-catenin signal pathway via $\beta$-catenin shRNA results in an inhibition of prostate cancer proliferation and invasion.
\end{abstract}

\section{Introduction}

$\mathrm{PCa}$ is the second most frequent cause of cancer-associated mortality in males in the USA (1). Various growth factors and cytokines have been reported to be associated with the

Correspondence to: Dr Yongguang Jiang, Department of Urology, Beijing Anzhen Hospital, Capital Medical University, 2 Anzhen Road, Beijing 100029, P.R. China

E-mail: yongguangjiangazyy@126.com

Key words: $\beta$-catenin, Wnt/ $\beta$-catenin signaling pathway, prostate cancer, short hairpin RNA progress of $\mathrm{PCa}$; however, the exact underlying molecular mechanism of $\mathrm{PCa}$ development and progression remains to be fully elucidated.

The Wnt/ $\beta$-catenin signaling pathway regulates pattern formation during embryogenesis and tumor progression. This signaling pathway activates various distinct intracellular pathways, which are involved in the proliferation, differentiation and polarity of cells. Aberrant activation of the Wnt/ $\beta$-catenin signaling pathway has been associated with tumor development and metastasis in numerous types of cancer (2-4).

During epithelial mesenchymal transition (EMT), epithelial cells alter morphologically, resulting in a loss of polarity and cell-to-cell contact. It has previously been demonstrated have indicated that during tumor progression, EMT is crucial for the invasion and metastasis of tumor cells (5). Our previous study demonstrated that the activation of the Wnt/ $\beta$-catenin signaling pathway is associated with the process of EMT and its role in the invasion and proliferation of tumor cells (6). The Wnt/ $\beta$-catenin signaling pathway was involved in EMT of human PCa induced by hypoxia-inducible factor (HIF) 1- $\alpha$ (7). The current hypothesized that the aberrant activation of the $\mathrm{Wnt} / \beta$-catenin signaling pathway may be involved the proliferation and invasive potency of $\mathrm{PCa}$. The present study aimed to investigate the expression and distribution of $\beta$-catenin in different prostate cancer cell lines. It was demonstrated $\beta$-catenin acted as an adhesion molecule in the LNCaP and C4-2 cell lines, and as a transcription factor of the Wnt/ $\beta$-catenin signaling pathway in the IF11-ARCaP and IA8-ARCaP cell lines. The results of the present study suggested that the aberrant activation of the Wnt/ $\beta$-catenin signaling pathway in IA8-ARCaP and IF11-ARCaP may be responsible for their high invasive potency.

RNA interference (RNAi) specifically inhibits the transcription of target genes, thus, reducing the corresponding protein levels, and has a high efficiency and specificity. In the present study, small hairpin (shRNA) targeting $\beta$-catenin was used to investigate the role of the $\mathrm{Wnt} / \beta$-catenin signaling pathway in human PCa cells in vitro.

\section{Materials and methods}

Cell culture and plasmids. PC-3, LNCaP, C4-2, IA8-ARCaP and IF11-ARCaP human PCa cell lines were obtained from Professor Dalin He, Xi'an Jiaotong University (Xi'an, China). 
Table I. shRNA targeted human $\beta$-catenin and sh-Control sequence.

\begin{tabular}{ll}
\hline Group & Sequence \\
\hline shRNA & 5'-GATCCCCACAGTCTTACCTGGACTCTTTCAAGAGAAGAGTCCAGGTAAGACTGTTTTTTA-3' \\
& 3'-GGGTGTCAGAATGGACCTGAGAAAGTTCTCTTCTCAGGTCCATTCTGACAAAAAATTCGA-5' \\
sh-Control & 5'-GATCCCCAACGAGTGTGCCTACATCCTTCAAGAGAGGATGTAGGCACACTCGTTTTTTA-3' \\
& 3'-GGGTTGCTCACACGGATGTAGGAAGTTCTCTCCTACATCCGTGTGAGCAAAAAAATCGA-5'
\end{tabular}

Table II. Specific primers for $\beta$-catenin and $\beta$-actin.

\begin{tabular}{lllr}
\hline Gene & Direction & \multicolumn{1}{c}{ Primer sequence (5'-3') } & Size (bp) \\
\hline$\beta$-catenin & Forward & ACTAAACAGGAAGGGATGGAAGG & 236 \\
$\beta$-catenin & Reverse & AGATGACGAAGAGCACAGATGG & 179 \\
$\beta$-actin & Forward & ATCGTGCGTGACATTAAGGAGAAG & \\
$\beta$-actin & Reverse & AGGAAGGAAGGCTGGAAGAGTG & \\
\hline
\end{tabular}

PC-3 cell lines were cultured in Dulbecco's modified Eagle's medium (DMEM), supplemented with $10 \%$ fetal bovine serum (FBS), $100 \mathrm{U} / \mathrm{ml}$ penicillin and $100 \mathrm{mg} / \mathrm{ml}$ streptomycin. LNCaP, C4-2, IA8-ARCaP and IF11-ARCaP were cultured in RPMI-1640 medium supplemented with 10\% FBS, $100 \mathrm{U} / \mathrm{ml}$ penicillin and $100 \mathrm{mg} / \mathrm{ml}$ streptomycin. DMEM and RPMI-1640 medium were purchased from Hyclone (GE Healthcare Life Sciences, Logan, UT, USA), and FBS was purchased from Gibco (Thermo Fisher Scientific, Inc., Waltham, MA, USA). $\beta$-catenin shRNA was constructed according to the protocol described in our previous study (7). Based on the vector sequence, the $\beta$-catenin shRNA target sequence and a sh-Control sequence (listed in Table I) were synthesized by Sunbiotech (Beijing, China). IA8-ARCaP cells were transfected with $\beta$-catenin shRNA using Lipofectamine 2000 ${ }^{\mathrm{TM}}$ (Invitrogen; Thermo Fisher Scientific, Inc.) according to the manufacturer's protocol.

Western blotting. Total protein was isolated from cultured cells using $300 \mathrm{ml}$ ice cold lysis buffer containing $1 \% \mathrm{NP}-40$, $50 \mathrm{mmol} / \mathrm{l}$ Tris ( $\mathrm{pH} 7.4$ ), $150 \mathrm{mmol} / \mathrm{l} \mathrm{NaCl}, 0.1 \%$ sodium dodceyl sulfate, $0.5 \%$ deoxycholate, $200 \mathrm{mg} / \mathrm{ml}$ phenylmethanesulfonyl fluoride and $50 \mathrm{mg} / \mathrm{ml}$ aprotinin. Insoluble materials were removed by ultracentrifugation at $15,000 \mathrm{x} \mathrm{g}$ for $30 \mathrm{~min}$ at $4^{\circ} \mathrm{C}$. The concentration of the extracted protein was measured spectrophotometrically with Coomassie G-250. Total protein $(50 \mu \mathrm{g})$ was loaded in each lane and resolved on a denaturing $12 \%$ SDS-PAGE gel. The proteins were transferred onto polyvinylidene fluoride membranes (PVDF) using a wet transfer method following polyacrylamide gel electrophoresis, then blocked with $3 \%$ bovine serum albumin (Santa Cruz Biotechnology, Inc., Dallas, TX, USA) for $1 \mathrm{~h}$ at room temperature and washed with Tris-buffered saline and Tween-20 three times. Antibodies specific for $\beta$-catenin (mouse anti-human IgG; 1:500; cat. no. sc-7963) and GAPDH (mouse anti-human IgG; 1:10,000; cat. no. sc-47724) were used to probe membranes, followed by peroxidase-conjugated secondary antibodies (goat anti-mouse IgG; 1:5,000; cat. no. sc-3697) and enhanced chemiluminescence detection (Sigma-Aldrich; Merck Millipore, Darmstadt, Germany). All primary antibodies were obtained from Santa Cruz Biotechnology, Inc. For quantification of band intensity, appropriate films were scanned and band densities were determined using Quantity One software (version 4.6.6; Bio-Rad Laboratories, Inc., Hercules, CA, USA), normalized against GAPDH, and presented as a ratio of control.

Reverse transcription-polymerase chain reaction (RT-PCR). Total RNA was extracted from the cell lines at $80-90 \%$ confluence using TRIzol ${ }^{\circledR}$ (Invitrogen; Thermo Fisher Scientific, Inc.). RNA ( $1 \mu \mathrm{g})$ was reverse transcribed using a RevertAid First Strand cDNA Synthesis kit (Fermentas; Thermo Fisher Scientific, Inc.). Amplification of $2 \mu \mathrm{l}$ cDNA was performed using Taq polymerase (Takara Bio, Inc., Otsu, Japan) with specific primers for $\beta$-catenin and $\beta$-actin (Table II). All primers were obtained from Sunbiotech. All PCR reactions were initiated with an incubation at $94^{\circ} \mathrm{C}$ for $2 \mathrm{~min}$, followed by 29 cycles of $94^{\circ} \mathrm{C}$ for $30 \mathrm{sec}, 58^{\circ} \mathrm{C}$ for $30 \mathrm{sec}$ and $72^{\circ} \mathrm{C}$ for 2 min. Reactions were finished with a $72^{\circ} \mathrm{C}, 10$ min extension step. PCR products were visualized by electrophoresis on $1.2 \%$ agarose gels and quantified with Quantity One analyzing software (version 4.6.6), normalized against $\beta$-actin, and presented as a ratio of control. All assays were performed at least 3 times.

Indirect immunofluorescence. To detect the expression and distribution of $\beta$-catenin, PCa cells were fixed in $10 \%$ paraformaldehyde for $30 \mathrm{~min}$ and blocked with goat serum (Santa Cruz Biotechnology, Inc.) for $30 \mathrm{~min}$. Cells were then incubated at $37^{\circ} \mathrm{C}$ for $1 \mathrm{~h}$ with a mouse anti-human $\beta$-catenin monoclonal antibody (1:200; Santa Cruz Biotechnology, Inc.; sc-7963). Following three washes with PBS, cells were incubated with a fluorescence isothiocyanate-conjugated goat anti-mouse antibody (1:100; Santa Cruz Biotechnology, Inc.; sc-3692) at $37^{\circ} \mathrm{C}$ for $1 \mathrm{~h}$. The fluorescence staining intensity and intracellular location were examined by fluorescence microscopy. 


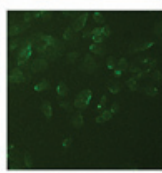

PC-3

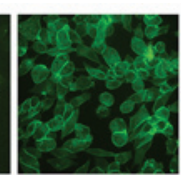

LNCaP

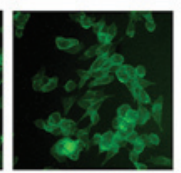

$\mathrm{C} 4-2$
IA8-ARCaP

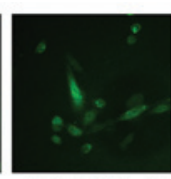

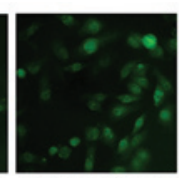

IF11-ARCaP
Figure 1. Expression and distribution of $\beta$-catenin protein in $\mathrm{PC}-3, \mathrm{LNCaP}$ C4-2, IA8-ARCaP and IF11-ARCaP cell lines. Indirect immunofluorescence was used to detect the expression and distribution of $\beta$-catenin protein in different prostate cancer cell lines. $\beta$-catenin was primarily localized in the cytoplasm and nucleus of IA8-ARCaP and IF11-ARCaP cells, whereas it was present in the membranes of $\mathrm{LNCaP}$ and $\mathrm{C} 4-2$ cell lines. There was low expression of $\beta$-catenin in PC-3 cell lines.

$\mathbf{A}$

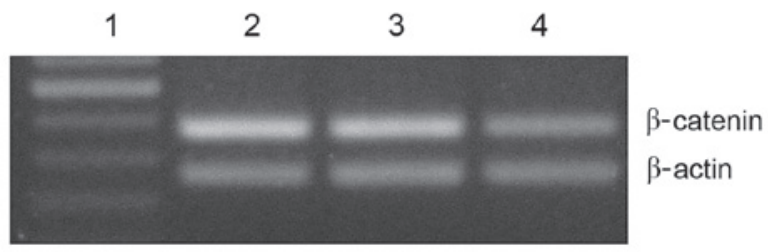

B

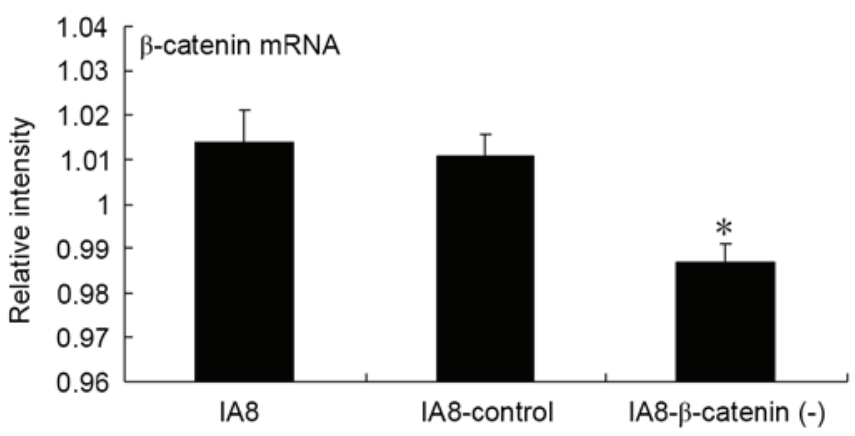

Figure 2. Inhibitory effects of $\beta$-catenin shRNA on $\beta$-catenin mRNA expression levels. (A) Reverse transcription-polymerase chain reaction analysis 1, 50 bp marker; 2 , IA8 group; 3 , IA8-shControl group; 4, IA8- $\beta$-catenin(-) group. (B) The mRNA expression levels of $\beta$-catenin in IA8- $\beta$-catenin(-) cells were significantly reduced compared with IA8 or IA8-shControl cells. Data are expressed as the mean \pm standard deviation $(n=3)$. ${ }^{*} \mathrm{P}<0.05$ vs. IA 8 and IA8-shControl. shRNA, short hairpin RNA; IA8- $\beta$-catenin(-), IA8-ARCaP cells transfected with $\beta$-catenin shRNA; IA8-shControl, IA8-ARCaP cells transfected with control shRNA.

MTT assay. The MTT assay was used to determine the proliferation of human PCa cells. PCa cells were seeded in 96-well plates and transfected with $\beta$-catenin shRNA. At various time points $(24,48$ and $72 \mathrm{~h}), 50 \mathrm{ml} 2.5 \mathrm{ng} / \mathrm{ml}$ thiazolyl blue tetrazolium bromide (MTT) solution was added into the cell culture plate and incubated with cells for an additional $4 \mathrm{~h}$. The media was collected separately from each chamber, and cell-associated MTT crystal was dissolved separately in $15 \mu \mathrm{l} /$ well dimethyl sulfoxide on a shaker at room temperature. Absorbance at a wavelength of $570 \mathrm{~nm}$ (proportional to viable cell number) was subsequently measured using a multiplate reader (Bio-Rad Laboratories, Inc.).

Matrigel Transwell assay. Transwell polycarbonate filters (8-mm pore size; EMD Millipore, Billerica, MA, USA) were coated with $50 \mathrm{ml}$ Matrigel (1:5; Sigma-Aldrich; Merck
Millipore) in serum-free medium and air-dried for $12 \mathrm{~h}$. Following this, $1 \times 10^{5}$ cells in serum-free RPMI-1640 were seeded into the upper chamber and $1 \mathrm{ml}$ RPMI-1640 with $20 \%$ FBS was added to the lower chamber. Human PCa cells: IA8-ARCaP cells, IA8- $\beta$-catenin, IA8-ARCaP cells transfected with $\beta$-catenin shRNA and IA8-shControl (IA8-ARCaP cells transfected with $\beta$-catenin sh-Control plasmid) were seeded into the upper chamber and allowed to migrate in a 5\% $\mathrm{CO}_{2}$ incubator at $37^{\circ} \mathrm{C}$ for $48 \mathrm{~h}$. Following incubation, a cotton swab was used to remove cells on the upper surface, and any invaded cells attached to the lower surface of the membrane were subsequently fixed with $4 \%$ paraformaldehyde and visualized with Giemsa stain (1:100) for $2 \mathrm{~h}$. Cell numbers were counted under a light microscope in 3 random microscopic fields (magnification, x10) per membrane.

Statistical analysis. Data are presented as the mean \pm standard deviation. All data analyses were performed using SPSS software version 13.0 for Windows (SPSS, Inc., Chicago, IL, USA). One-way analysis of variance (ANOVA) and independent-samples t-tests were conducted. Tukey's test was used for post hoc test following the ANOVA. All experiments were performed at least three times with similar results. $\mathrm{P}<0.05$ was considered to indicate a statistically significant difference.

\section{Results}

Expression and distribution of $\beta$-catenin in different $\mathrm{PCa}$ cell lines. $\beta$-catenin is a multifunctional protein involved in two processes, cell-to-cell adhesion and the Wnt/ $\beta$-catenin signaling pathway. To investigate the functional activities of the Wnt/ $\beta$-catenin signaling pathway in different PCa cells, the present study performed indirect immunofluorescence to detect the expression and distribution of $\beta$-catenin protein in PC-3, LNCaP, C4-2, IA8-ARCaP and IF11-ARCaP cell lines.

As presented in Fig. 1, there were marked differences in the expression and distribution of $\beta$-catenin between these cell lines. $\beta$-catenin was observed in the cytoplasm and nuclei of IA8-ARCaP and IF11-ARCaP cells, whereas it appeared to be present in the membrane of $\mathrm{LNCaP}$ and $\mathrm{C} 4-2$ cells. There was low expression of $\beta$-catenin in the PC- 3 cell line. Therefore, $\beta$-catenin may act as an adhesion molecule in the LNCaP and C4-2 cell lines, and as a transcription factor of the Wnt/ $\beta$-catenin signaling pathway in the IF11-ARCaP and IA8-ARCaP cell lines. This data indicated that the functional activity of $\mathrm{Wnt} / \beta$-catenin signaling pathway in IF11-ARCaP and IA8-ARCaP cells was greater compared with PC-3, LNCaP and C4-2 cells. IA8-ARCaP was therefore used as the cell model to further investigate the role of the $\mathrm{Wnt} / \beta$-catenin signaling pathway in $\mathrm{PCa}$.

Inhibition of mRNA expression by $\beta$-catenin shRNA. Our previous study successfully constructed $\beta$-catenin shRNA using gene recombination technology, which significantly decreased the expression of $\beta$-catenin in HEK-293 cell lines (6). In the present study, the effects of $\beta$-catenin shRNA on the expression of $\beta$-catenin mRNA in IA8-ARCaP cell lines were investigated. Fig. $2 \mathrm{~A}$ reveals the levels of $\beta$-catenin mRNA in IA8, IA8-shControl and IA8/ $\beta$-catenin(-) cell lines, as measured by RT-PCR. Statistical analysis demonstrated that 
A

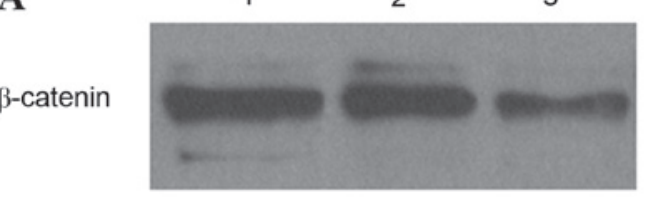

GAPDH

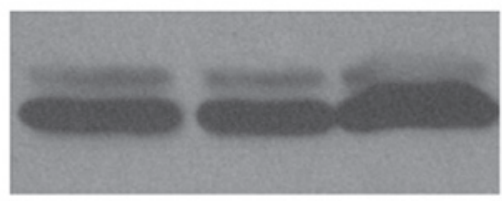

B

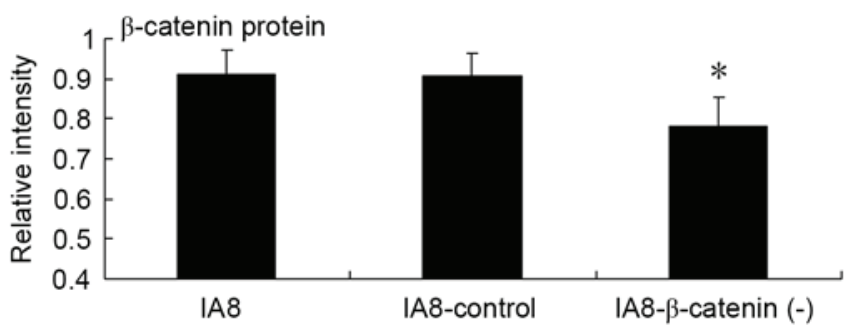

Figure 3. Inhibitory effects of $\beta$-catenin shRNA on $\beta$-catenin protein expression levels. (A) Western blot analysis. 1, IA8 group; 2, IA8-shControl group; 3, IA8- $\beta$-catenin(-) group. (B) Quantification of western blotting revealed that $\beta$-catenin protein expression levels in IA8- $\beta$-catenin(-) cells were significantly reduced compared with IA8 or IA8-shControl cells. Data are expressed as the mean \pm standard deviation $(n=3)$. ${ }^{*} \mathrm{P}<0.05$ vs. IA 8 and IA8-shControl. shRNA, short hairpin RNA; IA8- $\beta$-catenin(-), IA8-ARCaP cells transfected with $\beta$-catenin shRNA; IA8-shControl, IA8-ARCaP cells transfected with control shRNA.

the $\beta$-catenin mRNA expression levels in the IA8/ $\beta$-catenin(-) cell line was significantly downregulated compared with IA8 cells $(\mathrm{P}=0.002$; Fig. $2 \mathrm{~B})$. There was no significant difference between the IA8-shControl and IA8 groups.

Inhibition of $\beta$-catenin protein expression by $\beta$-catenin $s h R N A$. To further investigate the inhibitory effects of $\beta$-catenin shRNA on the Wnt $/ \beta$-catenin signaling pathway, the present study detected the expression of $\beta$-catenin protein using western blot analysis. The level of $\beta$-catenin protein in IA8, IA8-shControl and IA8/ $\beta$-catenin(-) cell lines is presented in Fig. 3A. Statistical analysis revealed that the protein expression levels of $\beta$-catenin in IA8/ $\beta$-catenin(-) was significantly decreased compared with IA8 and IA8-shControl group ( $\mathrm{P}=0.029$; Fig. 3B). There was no significant difference between the IA8-shControl and IA8 groups.

$\beta$-catenin regulates cell proliferation. As malignancy is associated with increasing cancer cell proliferation and invasion, the present study investigated the effect of $\beta$-catenin knockdown on proliferation in IA8-ARCaP cell lines. The growth potency of IA8, IA8- $\beta$-catenin(-) and IA8-shControl cells were assessed by MTT assay. As presented in Fig. 4, IA8- $\beta$-catenin(-) cells exhibited a reduced growth potency compared with IA8-shControl and IA8 cells $(\mathrm{P}=0.479$ at $24 \mathrm{~h}, \mathrm{P}=0.037$ at $48 \mathrm{~h}, \mathrm{P}=0.020$ at $72 \mathrm{~h}$ ), suggesting that $\beta$-catenin shRNA had an inhibitory effect on the proliferation of the IA8-ARCaP cell line. Suppressing the activity of the Wnt/ $\beta$-catenin signaling pathway via $\beta$-catenin shRNA resulted in growth inhibition of IA8-ARCaP cells in vitro.

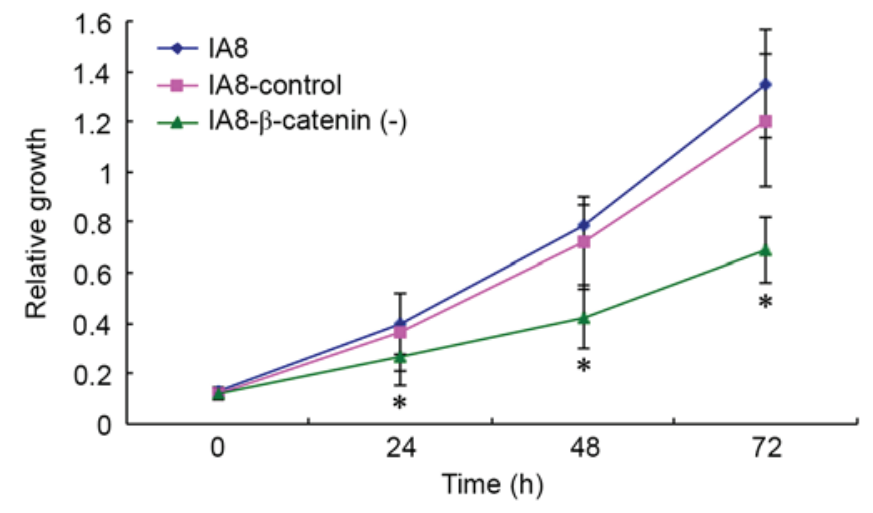

Figure 4. Knockdown of $\beta$-catenin inhibits the proliferation of IA8-ARCaP cells in vitro. The proliferation of IA8, IA8-shControl and IA8- $\beta$-catenin(-) cells was analyzed using an MTT assay. IA8- $\beta$-catenin(-) cells exhibited a reduced growth potency compared with IA8-shControl and IA8- $\beta$-catenin cells. ${ }^{*} \mathrm{P}<0.05$ vs. IA 8 and IA 8 -shControl. Data are expressed as the mean \pm standard deviation. IA8- $\beta$-catenin(-), IA8-ARCaP cells transfected with $\beta$-catenin short hairpin RNA; IA8-shControl, IA8-ARCaP cells transfected with control short hairpin RNA.

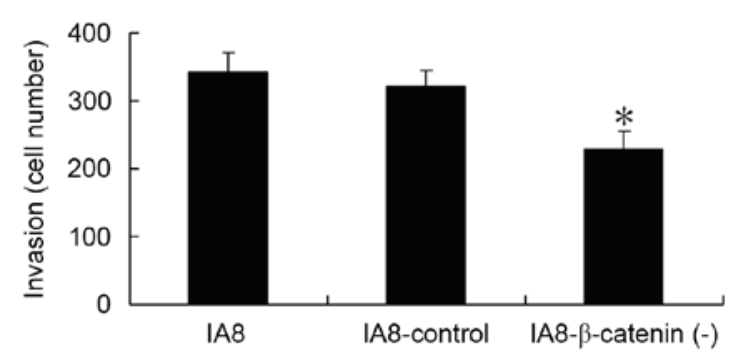

Figure 5. Knockdown of $\beta$-catenin inhibits the invasiveness of IA8 cell lines in vitro. IA8, IA8- $\beta$-catenin(-) and IA8-shControl cells were seeded onto Matrigel-coated filters. The number of cells on the underside of the filter was determined after $48 \mathrm{~h}$. Transfection with $\beta$-catenin shRNA resulted in a significant inhibition of IA 8 cell invasion. Data are expressed as the mean \pm standard deviation $(n=3)$. ${ }^{*} \mathrm{P}<0.05$ vs. IA 8 and IA8-shControl groups. shRNA, short hairpin RNA; IA8- $\beta$-catenin(-), IA8-ARCaP cells transfected with $\beta$-catenin shRNA; IA8-shControl, IA8-ARCaP cells transfected with control shRNA.

$\beta$-catenin regulates cell invasion. To further examine the role of the Wnt/ $\beta$-catenin signaling pathway in cell invasion of human PCa cells, a Matrigel Transwell assay was performed in vitro. The IA8, IA8/ $\beta$-catenin(-) and IA8-shControl cells were seeded into the upper chambers and $1 \mathrm{ml} \mathrm{RPMI}-1640$ containing 20\% FBS was added to the lower chambers. Cells were allowed to migrate for $48 \mathrm{~h}$. As presented in Fig. 5, the number of invading cells in the IA8/ $\beta$-catenin(-) group was significantly reduced compared with the IA8 and IA8-shControl groups $(\mathrm{P}=0.002)$. The results of the Matrigel Transwell assay demonstrated that inhibition of the Wnt $/ \beta$-catenin signaling pathway via $\beta$-catenin shRNA may result in an inhibition of $\mathrm{PCa}$ cell invasion in vitro.

\section{Discussion}

$\beta$-catenin exhibits a dual function in epithelial cells, depending on the intracellular localization. At the plasma membrane, $\beta$-catenin is a constituent of adherens junctions, and aids in 
cell-to-cell adhesion via binding to E-cadherin, and along with $\alpha$-catenin to the actin cytoskeleton. In addition, $\beta$-catenin acts as a key component of the Wnt $/ \beta$-catenin signaling cascade in the nucleus. Wnt protein binding to the seven-pass transmembrane receptors known as Frizzled proteins activates the signaling pathway, leading to $\beta$-catenin stabilization in the cytoplasm. Stabilized $\beta$-catenin subsequently translocates to the nucleus, where it associates with $\mathrm{T}$ cell factor/lymphoid enhancer factor-1 and promotes specific gene expression. Multiple key oncogenic proteins, including c-Myc, cyclin D1 and cyclooxyenase- 2 have been reported to be regulated by the Wnt/ $\beta$-catenin signaling pathway (8).

The aberrant activation of the Wnt/ $\beta$-catenin signaling pathway in premalignant and malignant cells results in uncontrolled cell proliferation, growth and survival of cancer cells, and therefore cancer progression. The Wnt/ $\beta$-catenin signaling pathway is a direct driver of thyroid transcription factor-1 expression, which is a tissue-specific transcription factor essential for thyroid differentiation (9). Dickkopf-related protein-1 (DKK-1), a secreted protein that binds to low density lipoprotein-related receptors $5 / 6$, blocks Wnt-1 protein signaling. Accumulation of DKK1 and cytoplasmic/nuclear $\beta$-catenin in triple negative breast cancers is indicative of poor prognosis. DKK1 expression alone or in conjunction with $\beta$-catenin may identify patients who may benefit from early systemic treatment (10). In addition, the canonical Wnt/ $\beta$-catenin signaling pathway regulates self-renewal of cancer stem cells and drug resistance of cancer cells $(11,12)$.

Previous studies have suggested that the $\mathrm{Wnt} / \beta$-catenin signaling pathway may be important in PCa. Chen et al (4) demonstrated that high levels of Wnt-1 and $\beta$-catenin expression were associated with advanced, metastatic, hormone-refractory $\mathrm{PCa}$, and may serve as biomarkers of disease progression. Another study indicated that promoting Wnt/ $\beta$-catenin activity via blocking DKK-1 promoted osteoblastic activity in osteolytic PC-3 cells, which suggested that the Wnt/ $\beta$-catenin signaling pathway contributed to the osteoblastic phenotype of PCa cell bone metastasis (13).

EMT is important for cancer growth and invasion. Our previous study demonstrated that the Wnt/ $\beta$-catenin signaling pathway is involved in EMT in human PCa and may be induced by HIF-1 $\alpha$ (5). In the current study, the role of the Wnt/ $\beta$-catenin signaling pathway in human PCa growth and invasion was investigated. Indirect immunofluorescence was used to detect the expression and distribution of $\beta$-catenin, the key component of the Wnt/ $\beta$-catenin signaling pathway in different human PCa cell lines.

The results of the present study indicated that in the $\mathrm{LNCaP}$ and C4- 2 cell lines, $\beta$-catenin localized in the membrane, whereas in the IA8-ARCaP and IF11-ARCaP cell lines, it was localized in the cytoplasm and nucleus. There was low expression of $\beta$-catenin in the PC-3 cell line. The EMT-positive cell lines IA8-ARCaP and IF11-ARCaP exhibited a greater level of cytoplasmic and nuclear $\beta$-catenin compared with the EMT-negative cell lines PC-3, LNCaP and C4-2. The activity of the Wnt $/ \beta$-catenin signaling pathway in the more invasive PCa cells IA8-ARCaP and IF11-ARCaP was markedly greater compared with LNCaP and C4-2 cells. IA8-ARCaP and IF11-ARCaP were established from the ascites of a patient with widely disseminated disease that represented a lethal form of human $\mathrm{PCa}$ with the ability to invade and metastasize aggressively to bone and soft tissue (14). The results of the present study suggested that the high functional activity of the Wnt $/ \beta$-catenin signaling pathway in IA8-ARCaP and IF11-ARCaP may be responsible for their high invasive potency.

RNA interference is the process of post-transcriptional, sequence-specific gene silencing in plants and animals, which was first introduced by Fire et al (15) in 1998, via experimentation in Caenorhabditis elegans. The process is initiated by shRNA homologous in sequence to the particular gene to be silenced. RNA interference is now a tool extensively employed in genetic engineering as a simple and effective gene knockdown technique. shRNA is an artificial RNA molecule with a tight hairpin turn that may be used to silence target gene expression via RNAi. shRNA is an advantageous mediator of RNAi in that it has a relatively low rate of degradation and turnover $(15,16)$. To further investigate the role of the Wnt $/ \beta$-catenin signaling pathway in PCa cells, $\beta$-catenin shRNA was used to suppress the activity of the Wnt $/ \beta$-catenin signaling pathway in IA8-ARCaP cell lines. The results demonstrated that the $\beta$-catenin-specific shRNA significantly suppressed the mRNA and protein expression levels of $\beta$-catenin, confirming that $\beta$-catenin shRNA may significantly inhibit the activity of the $\mathrm{Wnt} / \beta$-catenin signaling pathway.

As malignancy has been associated with increased cancer cell proliferation and invasion, the present study investigated the effects of $\beta$-catenin shRNA on proliferation and invasion. An MTT assay indicated that knockdown of $\beta$-catenin significantly inhibited the proliferation of the IA8-ARCaP cell line. A Matrigel Transwell assay revealed that $\beta$-catenin knockdown significantly suppressed the invasive activity of the IA8-ARCaP cell line, which suggested that the Wnt/ $\beta$-catenin signaling pathway regulated the proliferation and invasion of the IA8-ARCaP cell line. The data indicated that the high functional activity of $\mathrm{Wnt} / \beta$-catenin signaling in IA8-ARCaP cells was responsible for its high invasive potency.

In conclusion, the present study demonstrated that suppressing the functional activity of the $\mathrm{Wnt} / \beta$-catenin signaling pathway via $\beta$-catenin shRNA results in an inhibition of PCa proliferation and invasion. The results suggested that disrupting the $\mathrm{Wnt} / \beta$-catenin signaling pathway may represent an opportunity for rational and novel drug design for the treatment and prevention of $\mathrm{PCa}$.

\section{Acknowledgements}

The present study was supported by the program of the Science and Technology Development Foundation of Beijing Anzhen Hospital (grant no. 2013Z03).

\section{References}

1. Keller ET, Zhang J, Cooper CR, Smith PC, McCauley LK, Pienta KJ and Taichman RS: Prostate carcinoma skeletal metastases: Cross-talk between tumor and bone. Cancer Metastasis Rev 20: 333-349, 2001.

2. Fodde R and Brabletz T: Wnt/beta-catenin signaling in cancer stemness and malignant behavior. Curr Opin Cell Biol 19: $150-158,2007$. 
3. Guturi KK, Mandal T, Chatterjee A, Sarkar M, Bhattacharya S, Chatterjee U and Ghosh MK: Mechanism of $\beta$-catenin-mediated transcriptional regulation of epidermal growth factor receptor expression in glycogen synthase kinase 3 $\beta$-inactivated prostate cancer cells. J Biol Chem 287: 18287-18296, 2012.

4. Chen G, Shukeir N, Potti A, Sircar K, Aprikian A, Goltzman D and Rabbani SA: Up-regulation of Wnt-1 and beta-catenin production in patients with advanced metastatic prostate carcinoma: Potential pathogenetic and prognostic implications. Cancer 101: 1345-1356, 2004.

5. Luo Y, He DL, Ning L, Shen SL, Li L and Li X: Hypoxia-inducible factor-1alpha induces the epithelial-mesenchymal transition of human prostatecancer cells. Chin Med J (Engl) 119: 713-718, 2006.

6. Zhao JH, Luo Y, Jiang YG, He DL and Wu CT: Knockdown of $\beta$-catenin through shRNA cause a reversal of EMT and metastatic phenotypes induced by HIF-1 $\alpha$. Cancer Invest 29: 377-382, 2011.

7. Jiang YG, Luo Y, He DL, Li X, Zhang LL, Peng T, Li MC and Lin YH: Role of Wnt/beta-catenin signaling pathway in epithelial-mesenchymal transition of human prostate cancer induced by hypoxia-inducible factor-1alpha. Int J Urol 14: 1034-1039, 2007.

8. Schmalhofer O, Brabletz S and Brabletz T: E-cadherin, beta-catenin, and ZEB1 in malignant progression of cancer. Cancer Metastasis Rev 28: 151-166, 2009.

9. Gilbert-Sirieix M, Makoukji J, Kimura S, Talbot M, Caillou B, Massaad C and Massaad-Massade L: Wnt/ $\beta$-catenin signaling pathway is a direct enhancer of thyroid transcription factor- 1 in human papillary thyroid carcinoma cells. PLoS One 6: e22280, 2011.
10. Xu WH, Liu ZB, Yang C, Qin W and Shao ZM: Expression of dickkopf-1 and beta-catenin related to the prognosis of breast cancer patients with triple negative phenotype. PLoS One 7: e37624, 2012

11. Cai $C$ and Zhu $X$ : The $\mathrm{Wnt} / \beta$-catenin pathway regulates self-renewal of cancer stem-like cells in human gastric cancer. Mol Med Report 5: 1191-1196, 2012.

12. Cui J, Jiang W, Wang S, Wang L and Xie K: Role of Wnt/ $\beta$-catenin signaling in drug resistance of pancreatic cancer. Curr Pharm Des 18: 2464-2471, 2012.

13. Hall CL, Bafico A, Dai J, Aaronson SA and Keller ET: Prostate cancer cells promote osteoblastic bone metastases through Wnts. Cancer Res 65: 7554-7560, 2005.

14. Zhau HE, Odero-Marah V, Lue HW, Nomura T, Wang R, Chu G, Liu ZR, Zhou BP, Huang WC and Chung LW: Epithelial to mesenchymal transition (EMT) in human prostate cancer: Lessons learned from ARCaP model. Clin Exp Metastasis 25: 601-610, 2008

15. Fire A, Xu S, Montgomery MK, Kostas SA, Driver SE and Mello CC: Potent and specific genetic interference by double-stranded RNA in Caenorhabditis elegans. Nature 391: 806-811, 1998.

16. Elbashir SM, Harborth J, Lendeckel W, Yalcin A, Weber K and Tuschl T: Duplexes of 21-nucleotide RNAs mediate RNA interference in cultured mammalian cells. Nature 411: 494-498, 2001. 